\title{
KSIĘGOZBIORY KRAKOWSKIE ZAKONU BRACI MNIEJSZYCH - BERNARDYNÓW I REFORMATÓW - W ŚWIETLE NOT PROWENIENCYJNYCH W XVI-XVIII W.
}

\section{WPROWADZENIE}

Klasztory krakowskie pod wezwaniem św. Bernardyna i św. Kazimierza byly najstarszymi i przez długi czas największymi klasztorami bernardynów i reformatów w Polsce. Jako siedziby zarządów prowincji, konwenty te stwarzały zapotrzebowanie na wiele egzemplarzy dziel z różnych dziedzin, zwłaszcza zaś z zakresu teologii i filozofii. Żywe zainteresowanie także innymi poza teologią i filozofią, dziedzinami wiedzy w zakonie św. Franciszka $z$ Asyżu zostało bardzo silnie zaakcentowane już w wicku XIV przez angielskiego franciszkanina Rogera Bacona, który wyraził pogląd przyjęty w znaczej mierze przez caly Zakon, iż „studium teologii wymaga znajomości każdej innej ludzkiej wiedzy"1. To przeświadczenie znalazlo swój najbardziej wyrazisty przejaw w gromadzeniu bogatych księgozbiorów, zawierających dzieła $z$ różnych dziedzin nauki. W największych naukowych ośrodkach franciszkańskich średniowiecza, w Oksfordzie i Paryżu, a także Cesenie, Todi i Monteprandone, a w czasach nowożytnych w Salamance i Alacali, powstaly

* Używane skróty: Am - Amsterdam; An - Antverpen; APBK - Archiwum Prowincji oo. Bernardynów w Krakowie; APRK - Archiwum Prowincji oo. Franciszkanów-Reformatów w Krakowie; B. Czart. - Biblioteka im. XX. Czartoryskich w Krakowie; (bmw) - brak miejsca wydania; (brw) - brak roku wydania; BKRK - Biblioteka Konwentu Franciszkanów-Reformatów w Krakowie; BPBK - Biblioteka Prowincji oo. Bernardynów w Krakowie; F - Frankfurt am Maín; Gd - Gdańsk; Kr. - Kraków; KBPBK - Katalog BPBK; Lv - Leuven (Louvain); Lei - Leiden; Ly - Lyon; Mn - München; Ox - Oxford; SPTK - Slownik polskich teologów katolickich; Ve - Venezia.

1 H. Felder, Geschichte den wisseschaftlichen Studien im Franzisknnerorden. Freiburg im Brisgau 1904 s. 384. 
ogromne biblioteki. W samym zaś Asyżu biblioteka franciszkańska w konwencie św. Franciszka należala, obok Sorbony i papieskiej biblioteki w Awinionie, do największych w Europie. Już konstytucje zakonne z 1336 r., tzw. benedyktyńskie wydaly ścisłe przepisy nakazujace gwardianom przygotowywać co roku inwentarze biblioteczne. Ustalono też sankcje karne najwyższych wladz kościelnych, papieża Sykstusa V (1587) i Klemensa VIII, na tych wszystkich którzy ośmieliliby się niszczyć pomieszczenia biblioteczne lub zabierać książki bez zgody przelożonych ${ }^{2}$. Wszelkie ustalenia prawne odnośnie do bibliotek w prowincjach zakonnych oraz najlepsze wzory ich urządzania pochodzily z klasztorów zachodniej Europy, a zapoznawano się $z$ nimi $w$ trakcie trwania kapitul generalnych.

Zapotrzcbowanie na książki i księgozbiory pozostawało w lączności z różnyymi sferami dzialalności zakonu. Obok starań o wewnętrzne uświęcenie i rozwijanie działalności duszpasterskiej, które po Soborze Trydenckim znacznie się wzmogly, organizowano na nowo, lub reformowano, już istniejące studia zakonne, przygotowujące kandydatów do kaplaństwa i formujące kaznodziejów i spowiedników. Reforma studiów po Soborze Trydenckim zmuszala do tworzenia nowych, względnie poszerzania już istnicjacych bibliotek w klasztorach studiów. Kapitula w Kazimierzu Biskupim w 1591 r. zobowiązywala nawet do pewnej centralizacji książek potrzebnych studiującym, aczkolwiek jej uchwaly nie zostaly na razie wprowadzone $w$ życie ${ }^{3}$. Potrzeby dnia codziennego zmuszały do nabywania także i dziel medycznych, pomocnych $w$ prowadzeniu aptek klasztornych i obsługiwaniu infirmerii, w których leczono zakonników nie tylko krakowskich lecz również przybywajacych tu na leczenie $z$ innych ośrodków. Zaopatrywano także w leki ludzi z zewnątrz, proszacych u furty o pomoc medyczną. Wszystko to sprzyjało rozbudzeniu zainteresowania nowymi książkami, naplywającymi do bibliotek droga fundacji, od poszczególnych dobrodzicjów, a także przywożonymi przez prowincjałów i studentów przebywajacych na zachodzic Europy.

Nastepne kapituly, odprawione w Warcie (1599), Krakowie (1617) i w Kalwarii Zebrzydowskiej (1623) wydaly kolejne szczegółowe uchwaly o bibliotekach. Pierwsza $z$ nich zabronila przywlaszczania książek dla celów prywatnych, kalwaryjska nakazala gwardianom nabywać co roku nowe książki, zapewnić im odpowiednio obszerne i wyremontowane pomieszczenia, a kapituła krakowska nakazała ustanawiać bibliotekarzy klasztornych osobna nominacja prowincjała ${ }^{4}$. Wolno było wypożyczać ksiażki lektorom, ale na krótko, i to za pozwoleniem przelożonego i wiedzą bibliotekarza, z obowiązkiem pozostawienia własnoręcznie podpisanego rewersu ${ }^{5}$. Wspomniano

\footnotetext{
2 Bullarium Franciscanum. T. 7. Ed. a C. Eubel. Romae 1904 s. 522.

3 K. Kantak, Bernardyni..., t. 2, s. 300, 301.

4 B. Czart. Rkp. XVII/2469: Anngriphe (II) s. 292, 293.

5 Tamże s. 393.
} 
w uchwalach nawet o karze ekskomuniki papieskiej Sykstusa $V w$ przypadku zawlaszczenia mienia wspólnego, jakie stanowily zasoby biblioteczne. Do tego rodzaju nadużyć podpadających ekskomunice papieskiej zaliczono również m.in. wycinanie kart pergaminowych z ksiagg liturgicznych ${ }^{6}$.

Biblioteki w Prowincji NMP Anielskiej Reformatów od początku ich powstania $w$ Polsce byly organizowane niejako samorzutmie przy nowo powstajacych klasztorach. Z nakazu konstytucji generalnych z 1642 r. książki mialy być nabywane "z prowizji majątku klasztornego" oraz ze środków finansowych osób wstepujacych do zakonu. Następnie mialy być "skatalogowane i przechowywane iw zamknięciu"'.

Już uprzednio zaznaczono, iż klasztory bernardynów i reformatów podobnie jak i konwenty wcześniejszego w Polsce zakonu franciszkanów konwentualnych, zrealizowały podstawowe cele swojego istnienia i dzialania m.in. przez gromadzenic zasobnych bibliotek. Istnieje nawet przypuszczenie, że pierwszy druk w Polsce, mianowicie "Almanach" na rok następny (1474) tłoczony przez wędrownego drukarza Kaspra Straubego w 1473 r., ukazał się nakładem krakowskich bernardynów, i prawdopodobnie na terenie ich stradomskiego konwentu ${ }^{\delta}$. Każdy bernardyński klasztor posiadał większy lub mniejszy księgozbiór, którego zrąb tworzyly rękopiśmienne księgi liturgiczne pochodzace $z$ dotacji dobrodziejów. Bogate piśmiennictwo, ukazujące się w oficynach europejskich schylku reformacji i w wieku XVII, a jeszcze bardziej wskazania Soboru Trydenckiego skłoniły bernardynów, a także przybyłych po soborze do Polski reformatów, do nabywania nowej literatury, szczególnie z zakresu filozofii i teologii. Obok wielu podobieństw między księgozbiorami obu wymienionych formacji tego zakonu, rozwijających te same kierunki dzialalności, istniały jednak wśród nich pewne różnice wynikajace $z$ rozbieżności czasowych w ich gromadzeniu i uzupełnianiu. Biblioteka Prowincji Bernardynów przy klasztorze krakowskim $w$ dzisiejszych swych rozmiarach opiera się na najstarszym bemardyńskim ksiegozbiorze konwentu krakowskiego, wzbogaconym o zbiory, względnie ich fragmenty, przejęte po 2. wojnie światowej ze Lwowa, Sambora, Sokala, a także z Alwernii, Koła, Tarnowa i z innych klasztorów na terenie Polski.

Księgozbiór przy klasztorze św. Kazimierza ze względu na nowicjat i mieszczace się $w$ nim studia posiadał również dziela sprowadzone $z$ innych klasztorów, ale byly to uzupełnienia sporadyczne i nie na tak szeroka skalę, jak $w$ klasztorze św. Bernardyna. Księgozbiór ten stanowi w zasadzie tylko jedyna uwzględniana przez nas bibliotekę reformatów, aczkolwiek najstarszą i największa spośród bibliotek tego ugrupowania franciszkanów w Polsce. Ponadto, jak już wspomniano, w XVII w. reformaci tworzyli swoje księgozbiory

6 Tamże.

7 A.B. Sroka, Prawo $i$ życie polskich reformnntów. Kr. 1975 s. 146.

8 W. Szelińska, Druknrstwo krakowskie. Kr. 1974 s. 9. 
klasztorne od podstaw, w miare powstawania ich nowych klasztorów, natomiast u bernardynów gromadzenie książek po Soborze Trydenckim stanowilo kontynuacje gromadzenia wcześniejszego i powiększania pokaźnych już zbiorów zapoczątkowanych $w$ drugiej polowie $X V w$.

Wzmianki w nekrologach o pierwszych lektorach i kaznodziejach konwentu św. Bernardyna, którzy zdobyli wyksztalcenie w Akademii Krakowskiej, a następnie wstąpili do zakonu, wskazują na ludzi, dla których pierwotny księgozbiór byl warsztatem codziennej pracy. W konwencie krakowskim powstały dziela pierwszych autorów-zakonników: m.in. prawdopodobnie "Legenda św. Stanislawa” Stanislawa Magistra, "Breviloqium” Jana ze Stopnicy, "Opis Jerozolimy" Anzelma Polaka i "Kronika zakonu Braci mniejszych" Jana z Komorowa ${ }^{9}$. W okresie nasilenia reformacji, a jeszcze bardziej po Soborze Trydenckim, biblioteki bernardyńskie z krakowską na czele uzyskaly wydania Biblii i komentarzy biblijnych, a także wiele dzieł Ojców Kościoła, wydanych w XV i XVI $w$. oraz innej literatury $z$ okresu wczesnego chrześcijaństwa, a także aktualnej niemieckiej literatury polemicznej $w$ języku lacińskim, potrzebnej kaznodziejom. Do tych zrębów, jakie stanowiły nabytki z XV i pierwszej polowy XVI w. doszła pod koniec trwania Soboru Trydenckiego i w okresie posoborowym, do końca XVII w., większość zasobów obecnej Biblioteki Prowincji. Szczyt ilościowy $w$ tym napływie książek byl związany, jak się wydaje $z$ ogólnym ruchem odnowy intelcktualnej $w$ Kościele $i \mathrm{w}$ zakonie, spowodowanym reformacja, a następnie obradami i uchwałami Soboru.

\section{NOTY WŁASNOŚCIOWE I PROWENIENCYJNE KRAKOWSKIEJ BIBLIOTEKI BERNARDYNÓW}

Znaczna część książek w bibliotekach klasztornych bernardynów pochodziła $z$ darów szlachty, powracającej $w$ drugiej polowie XVI w. i w wieku XVII do katolicyzmu. W ten sposób trafily do klasztorów pozycje protestanckie, gromadzone przez sympatyków reformacji, których dzieci i wnukowie powrócili na lono Kościoła katolickiego. Wśród dobrodziejów biblioteki konwentu św. Bernardyna $w$ Krakowie $w$ drugiej polowie XVI w. znalazł się przede wszystkim pleban skalmierski, Stanisław Sulima, który przekazał zakonnikom 25 książek, 7aznarzaj̣ạ na piśmie, że przeznacza jue ..dla pobożnego klasztoru krakowskiego" (Pro devoto loco Cracovieviensi) ${ }^{10}$. Z kolei w 1603 r. podkanclerzy koronny bp Piotr Tylicki złożyl ofiarę, zapewne na ręce swojego spowiednika Andrzeja Rochmana, na kupno dzieła franciszkańskiego teologa rodem z Hiszpanii, Jana Rady „O kontrowersji teologicznej między Tomaszem

9 K. Kantak, Bernardyni... t. 1 s. 77.

10 Tenże, Dzieje krakowskich Bernardynózo. W: K. Kantak., J. Szablowski, J. Zarnecki, Kościól i klasztor oo. Bernardynów w Krakotvie. Kr. 1938 s. 34. 
a Scotem" (1599)"11., a w 1607 r. już jako ordynariusz krakowski ofiarowal Rochmanowi dwa tomy dziela św. Bonawentury. Dobrodziejka klasztoru bernardynów w Poznaniu, Zofia $z$ domu Opalińska, żona przywódcy różnowicrców Andrzeja Leszczyńskiego, a matka późniejszego prymasa Wacława finansowala między rokiem 1614 a 1620 kupno innego dziela Rady, pt. "Kontrowersje na trzeci tom Sentencji Lombarda". Za 3 złp nabyl je w Poznaniu Leonard Starczewski i otrzymal zgodę prowincjala na wlaczenie tej pozycji do wlasnego księgozbioru podręcznego ${ }^{12}$. Bez problemu mógl więc zabrać nabyte dzielo do klasztoru krakowskiego, do którego zostal przeniesiony. Równie cenny dar dla nieznanego kaznodziei krakowskiego złożył na początku lat 40-tych XVII w. biskup warmiński, Mikolaj Szyszkowski h. Ostoja, w postaci "Dziel wszystkich" św. Bernardyna ze Sieny w opracowaniu Jana La Haye ${ }^{13}$.

W drugicj polowie XVII w. do wybitniejszych dobrodziejów biblioteki konwenckiej św. Bernardyna należal miecznik koronny Michał Zebrzydowski, który w 1660 r. przekazal ze swego zbioru cenione wówczas dzieło o charakterze encyklopedycznym - „Polianteae” Jana Grutera ${ }^{14}$. Mial w tym zapewne zasluge ówczesny prowincjał Franciszek Dzielowski, który dzieło przejal osobiście wyłaczając je, być może, z bogatego zbioru z Pieskowej Skały, który miecznik przekazal w całości konwentowi w Kalwarii Zebrzydowskiej ${ }^{15}$.

$\mathrm{Na}$ podstawie not proweniencyjnych księgozbioru krakowskiego można stwierdzić, że najwięcej książek pochodzilo od samych zakonników, którzy otrzymywali je na wyposażenie biblioteki studium od znanych ofiarodawców. Czasami prowincjał wyrażal zgodę na dożywotnie użytkowanie potrzebnych im $w$ pracy dziel. Po śmierci użytkownika dana pozycja zostawala włączona do biblioteki klasztornej i pozostawala do dyspozycji kaznodziejów i lektorów krakowskich. Te prywatne zbiory poszczególnych zakonników wytykali bernardynom reformaci, uznając to za nadużywanie ślubów ubóstwa ${ }^{16}$. Nie ulega watpliwości, iż indywidualne zainteresowania i starania poszczególnych zakonników o nabywanie potrzebnych dziel stanowily jedno z ważnych źródel powiększania biblioteki klasztornej, a zarazem studyjnej.

Niejako z obowiązku przekazywali swoje książki konwentowi krakowskiemu i innym ważniejszym klasztorom sami autorzy bernardyńscy.

11 J. Rada, Conttozersine theologicne inter. Thomam et Scotum. Venetiis 1699 (KBPBK) (Nota proweniencyjna na karcie tyt.).

12 Tenże, Controversiae super 3. Sententiarum Librum. Romae (ok. 1614) (Nota wlasnościowa na karcie tyt. - KBPBK).

13 S. Bernardinus Senensis, Opera omnin. Parisiis 1636. Nota dedykacyjna z nazwiskiem bpa M. Szyszkowskiego znajduje się na karcie przedtytulowej. - KBPBK).

$1+$ J. Gruterus, Florilegii Mngni seu Poliantheae. T. 2. Argentorati 1624 (Nota proweniencyjna in verso karty tytulowej. - KBPBK).

15 H. Eug. Wyczawski, Knlwarin Zebrzydowskn..., s. 187.

16 K. Kantak, Bernardyni... T. 2 s. 303. 
Hannibal Rosselli, filozof i teolog ofiarowal tom dziewiaty swojego slynnego "Pymandra" bibliotekom konwenckim w Krakowie i Alwerni. Nie zapomnial także o kaznodziejach we Lwowie i Samborze. Obdarzyl równicż opasłym woluminem innego wspólbrata samborskiego, Leonarda Górskiego, zwanego Montanus. Zachowal się też egzemplarz dedykowany osobistemu spowiednikowi autora $w$ klasztorze stradomskim - nie znanemu nam $z$ nazwiska, o. Jakubowi. Pewnym dowodem znaczenia biblioteki konwenckiej na Stradomiu z początkiem XVIl w. oraz dobrego wspólżycia bernardynów z dominikanami był dar Abrahama Bzowskiego w postaci wlasnego, świeżo wydanego dziela pt. „Zlote kwiaty..." (Flores aurei), przekazany $w$ rok po wydaniu ${ }^{17}$. Przekazywali swoje dzieła bibliotece również pisarze bernardyríscy, m.in. Florian Kolęcki, wydawca wykładów swojego mistrza Andrzeja Rochmana; czolowy teolog skotystyczny w Polsce, Piotr z Poznania ${ }^{18}$; kaznodzieja katedralny w Krakowie i prowincjal, Antoni Stafanowicz.

Przykładem nabywania książek dla wspólnoty zakonnej była akcja Benedykta Gąsiorka, absolwenta studium paryskiego. Kiedy w 1585 r. powrócił do kraju, otrzymal polecenie kapituly obradujacej $w$ tym roku w Warszawie, zorganizowania studium filozofii $w$ Samborze. Gassiorek pozyskal możnego dobrodzieja w osobie Jerzego Mniszcha i zapewne $z$ jego pomoca wyposażył samborską bibliotekę $w$ liczne dzieła filozoficzne i teologiczne ${ }^{19}$. Inny lektor, Antoni Oczko, zgromadzil księgozbiór sokalski, kwestując u dobrodziejów zakonu za książkami ${ }^{20}$. Z kolei lektor Jan Cieciszowski, przebywajacy w Bolonii $w$ latach 80-tych XVI w., nabył „Lugikę” (Organum) Arystotelesa z jałmużny prowincjalskiej. Po powrocie do kraju nabyl jeszcze wiele innych książek, które następnie w latach 1589, 1597 i 1599 przeznaczył do biblioteki konwenckiej i studium $w$ Warszawie ${ }^{21}$. Nie brakło również lektorów i studentów, którzy nabywali ksiażki z myślą o indywidualnych swoich potrzebach. Do nich należal Krzysztof Scipio de Campo, glośny ze sporów o krakowski klasztor bernardynów zwany Żlóbkiem. Zakupując książki dla domu zakonnego przy ulicy św. Jana nie omieszkał zaznaczyć, że przeznaczone są na użytek własny.

17 Tamże, s. 318.

is Wiemy o tym m.in. $z$ not proweniencyjnych w zachowanych do dzis ksiazkach w BPBK. Np. czolowy teolog i skotysta w wieku XVII Piotr z Poznania (Bliński) dal swoje "Konlentarze do 2 Ksiggi Sentencji Scota" (wyd. 1654) krakowskim lektorom teologii, a "Komentarz to 3 Ksiegi Sentencji" otrzymala biblioteka konwentu stradomskiego. Z kolei drugi egzemplarz tegoż dziela ofiarowal bernardynom na Stradomiu, nieznany bliżej student krakowski Jan Esbechowicz (?).

19 K. Kantak, Bernardyni..., t. 2 s. 13.

20 Tamze, s. 25.

21 Tamże, s. 34. 
Do największych księgozbiorów powstalych droga prywatnych starań, które później włączono do biblioteki konwentu krakowskiego, należał na początku XVII w. ksiegozbiór przywieziony do Alwerni przez Piotra z Poznania?2. Usteppował on tylko bibliotece klasztoru w Skępem, urządzonej przez Ludwika ze Zbąszynia (1651-1654)23. Jego uzupelnieniem $w$ klasztorze alwernijskim byly dary książkowe okolicznego duchowieństwa, które zaczęlo przekazywać uczonemu zakonnikowi, a po jego śmierci klasztorowi, swe książki. Wśród tych ofiarodawców należy wymienić: plebana Jana Kosznickiego z Tenczynka; plebana $z$ Chrzanowa i Bibic, Jana Stefanowicza ${ }^{24}$ oraz plebana regulickiego, Jana Chrapowskiego. Dwaj ostatni złożyli swoje dary już po śmierci Piotra (zm. 1655). Księgozbiór klasztoru w Alwerni, którego zasadniczy zrąb stanowily dziela zebrane przez Piotra z Poznania zwrócil uwagę lektorów teologii, klasztoru stradomskiego i dlatego zarząd prowincji znaczną jego czesść przeznaczył w 1703 r. dla krakowskiego studium ${ }^{25}$. Cala reszta zostala wcielona do Biblioteki Prowincji Bernardynów w Krakowie po drugiej wojnie światowej.

$Z$ reforma studiów zakonnych, względnie $z$ nowa ich organizacją $w$ nowych klasztorach wiązało się organizowanie i bardziej planowe zaopatrywanie bibliotek w klasztorach studiów ${ }^{26}$. Nabywano więc przede wszystkim dziela specjalistyczne $z$ zakresu teologii i filozofii, prawa kanonicznego, historii Kościola, a także retoryki i dialektyki. W kwestii organizowania bibliotek dla lektorów i studiujących przelomowe stały się uchwały kapituly w Kalwarii Zebrzydowskiej z 1623 r. a szczególnie trzeci paragraf rozdziału „De reformatione".

Uchwała biblioteczna tej kapituły nakazywała przełożonym miejscowym zajęcie się - zaraz po powrocie $z$ obrad - reorganizacja względnie odnowa bibliotek w podleglych klasztorach. Przewidziano nawet tworzenie księgozbiorów calkowicie od podstaw $w$ domach, gdzie nie pomyślano o tym wcześniej ${ }^{27}$. Także inne kapituły zajmowały się problemem właściwego funkcjonowania bibliotek w klasztorach. W 1617 r. kapituła obradująca w Krakowie zobowiazzala prowincjala do ustanowienia bibliotekarzy dla poszczególnych konwentów. Mieli oni pilnować zbiorów i za zgoda przełożonego wypożyczać książki braciom, szczególnie lektorom i kaznodziejom. Nakazano również przelożonym ustępującym i nowo mianowanym ścisła kontrolę nad książkami, szczególnie tymi, które znalazły się poza obrębem biblioteki, a więc i w poszczególnych celach klasztornych. Przelożeni mieli dbać o sporządzenie in-

\footnotetext{
22 H. Eug. Wyczawski, Alwentia. Dzieje klasztoru oo. Bernardynów. Kr. 1957 s. 96, 97.

23 K. Kantak, Bernardyni..., t. 2 s. 352.

24 H. Eug. Wyczawski, Alwernia..., s. 97.

25 Tamże.

26 K. Kantak, Bernardyni..., t. 2 s. 300.

27 B. Czart. Rkp. XVII/2469: Anagriphe (II) s. 392, 393 nr 1, 2.
} 
wentarza książek z obowiązkiem przekazania go swoim następcom. Wcześniejsze kapituly prowincjalne: w Warcie (1588) i Samborze (1597) wydając te nakazy nawiązywaly do odnośnych rozporządzeń Stolicy Apostolskiejej. Książki specjalistyczne zakresu teologii i filozofii, szczególnie mniej konieczne dla zakonników danego klasztoru, miały być - zgodnie z nakazem kapituły samborskiej (1597) - skladane na osobnym miejscu i nie wlączane do biblioteki klasztornej, ale jak już wspomniano, odsylane do domów studiów. Dla dopilnowania tego polecenia mial być wyznaczony osobny zakonnik ${ }^{29}$. Natomiast książki dane braciom do użytku prywatnego nie mogly być początkowo przewożone do innych klasztorów. Jedynie w poszczególnych przypadkach dawal na to zgodę prowincjal ${ }^{30}$. W końcu jednak, na skutek interpelacji wniesionej do zarządu generalnego zakonu w tej sprawie, kapitula generalna w Toledo w 1606 r. zezwolila poszczególnym braciom w czasie przenoszenia się do innego konwentu zabrać ze soba tyle książek ile uniesie jeden koń na swoim grzbiecie ${ }^{31}$. Natomiast książki po zmarlych braciach miały być - zgodnie z ustaleniami kapituły w Samborze - rozdzielone przez prowincjała pomiędzy biblioteki innych klasztorów lub po prostu włączone do biblioteki miejscowej.

$W$ drugiej polowie XVIl w. kapituly prowincjalne ponownie zwrócily uwage na sporządzanie od nowa katalogów bibliotecznych ${ }^{32}$. W praktyce przelożeni ograniczyli się do przygotowania inwentarza dziel, zaznaczając $w$ nim pobieżnie nazwisko autora, przeważnie bez imienia, wraz z pierwszymi slowami tytułu książki, ilość woluminów, oraz ilość egzemplarzy tego samego dzieła, natomiast bez zaznaczania miejsca i roku wydania ${ }^{33}$. Na tej samej kapitule zwrócono też przelożonym uwage na obowiązek ciagłego nabywania nowych dziel ${ }^{34}$.

Na wielu książkach Biblioteki Prowincji Bernardynów w Krakowie można zauważyć napisy świadczace o ich związku ze studiami np. „Księga ruchoma"(liber mobilis) przeznaczona dla studium gdziekolwiek by je umieszczono, także z napisem "dla studentów Polaków w Rzymie" (pro studentibus polonis Romae) ${ }^{35}$. Tego rodzaju adnotacje umieszczano za zgodą prowincjala, który przede wszystkim byl odpowiedzialny za stan i zaopatrzenie $w$ nowości

28 Tamże, s. 394 nr 1.

29 Tamże, s. $394 \mathrm{nr} 3$.

30 Tamże, (Uchwala kapituly obradującej w Warszawie w 1626 roku - nr 4).

31 Tamze, s. $3 \dot{9} 5 \mathrm{nr} 4$.

32 K. Kantak, Bernardyni..., t. 2 s. 302.

33 Znane sa trzy takie inwentarze, z 1680, 1704 i 1763 r. - APBK Rkp. I-h-1, Inventarium librariae conventus Cracoviensis ad S. Bernardinum ab a.D. 1677 ad. a. 1680 collectum et auctum; Rkp. I-h-2, Inventarium bibliothecae conventus Cracoviensis ... conscriptum a.D. 1704 pro capitulo Grodnensi a P. Fratre Erasmo Kozikiewicz...; Rkp. I-h-3, Regestrum librorum bibliothecae conventus custodialis Cracoviensis ... per F.P. Brunonem Lazarowic ... a.D. 1763 conscriptum.

${ }^{3+}$ K. Kantak, Bernardyni..., t. 2 s. 302.

35 Tamże, s. 300. 
bibliotek studiów. Niektórzy z prowincjalów w XVI i XVII w. wyróżnili się szczególną gorliwością w nabywaniu książek za granica i w kraju, i korzystając z uprawnień udzielonych im przez kapitułę prowincjalną w Samborze (1597) bardzo wiele książek po zmarłych zakonnikach przekazali bibliotekom klasztorów studyjnych, szczególnic krakowskiemu, lwowskiemu i samborskiemu. Do najbardziej zaslużonych w powiększaniu bibliotek studiów we Lwowie i Samborze w drugiej połowie XVI w. należeli prowincjałowie: Gabriel z Czerniejewa, Benedykt Gąsiorek, Hicronim Przybiński i Jan Kapistran Krzeciek ${ }^{36}$. Jeśli natomiast chodzi o konwent krakowski św. Bernardyna, to wedlug zapisów proweniencyjnych książek należących do tej placówki najwięcej tego rodzaju przekazów uczynili w wieku XVII: Hieronim Kakowski (14), Krzysztof Scipio de Campo (9), Krzysztof Strzala (9), Aleksy Piotrkowczyk (7), Jacek Stradomski (5) i Franciszek Dzielowski (5).

Stosunkowo dużo pozycji dla studium teologii w Krakowie, a zarazem dla stradomskiego konwentu, przekazal Hieronim Kakowski, wizytator prowincji w 1645 r. po burzliwym okresie rządów Krzysztofa Scipio de Campo, sygnujac je swoim nazwiskiem. Byly to przeważnie dzieła podręcznikowe lub zastępujące podręczniki, m.in. dziela Jana Dunsa Scota z komentarzem Franciszka Lichetty w wydaniu liońskim z 1639 r., następnie „Dysputy teologiczne o Trójcy Sw. wedlug Tomasza z Akwinu" autorstwa kapucyna Jana Zamory ${ }^{37}$ oraz podręcznik szkolny innego kapucyna, Ludwika Caspensis ${ }^{3 \hat{8}}$.

Drugie miejsce w zapisach proweniencyjnych książek należących do studium teologii w Krakowie zajmuje Krzysztof Scipio de Campo, wykształcony w Rzymie, Salamance i Alcali, czlowiek niezmiernie ruchliwy i wywierający zasadniczy wpływ na życie prowincji bernardyńskiej w latach 1614-1628. Posiadał on szereg dziel do wlasnego użytku, ale dbał równieź o zaopatrywanie bibliotek klasztornych, szczególnie krakowskich. Wśród nabytych przez niego byly m.in. „Dysputy teologiczne" Fabera ${ }^{39}$, "Kwestie subtelne" J.D. Scota i wykład "Metafizyki" Arystotelesa w opracowaniu Hugona Cavellusa (będący prywatną wlasnościa Campo ${ }^{40}$ ) oraz „Kwestie teologiczne..." Tomasza Franciszka Albertino de Catanzara ${ }^{41}$, odstąpione nieznanemu z nazwiska lektorowi warszawskiemu Tomaszowi następnie dzieło prawnicze hiszpańskiego

36 Tamże, s. 302.

37 J.M. Zamora, Disputationes theologicae de Deo uno et trino. Ve 1626 (KBPBK).

38 L. Caspensis, Cursus theologicus ... materine qune in scholis trati solent. Ly 1641. - Notin prowen. in verso karty tytulowej (KBPBK).

39 Pl. Faber (Faventinus:), Disputationes theologicne. Ve 1613. - Na k. tyt. nota z nazwiskiem K. Scipio de Campo (KBPBK).

${ }^{40} \mathrm{H}$. Cavellus, Jonmis Duns Scoti ... Qunestiones subtilissimue et expositio in Metaphisicam Aristotelis. Ve 1625 (KBPBK).

41 Franciscus A. de Catanzara, Corollarin set qunestiontes theologicne ... in Thomnm ... Ly 1610. Nota z nazwiskiem Campy i klasztoru Żlóbek w Krakowie, 1613 r., w której zezwala on jako prowincjal na prywatny użytek tej ksiażki lektorowi Tomaszowi z Warszawy (KBPBK). 
kanonisty zakomego, Emanuela Rodricusa pt. „Kwestie zakonne" 2 i "Komentarze do czterech ksiag Sentencji" Jana de Bassolis ${ }^{43}$. Te ostatnie stanowiły prywatna wlasność Campo i dopiero po jego śmierci zostały włączone do biblioteki klasztoru na "Żlóbku” w Krakowie. Zachowała się też notka Campo na dziele Piotra z Poznania pt. "Komentarze do pierwszej ksiegi Sentencji” (Moguntiae 1612), przeznaczająca je dla studium teologii w Wilnie, w 1617 r.

O ile Krzysztof Scipio de Campo dysponowal wielona prywatnymi ksiązkami, których pewna ilość przywiózl z Hiszpanii i Wloch, to Krzysztof Strzała, wikariusz prowincji malopolskiej w latach 1653-1656, po zmarlym na urzędzie Florianie Grodeckim - przeznaczył pewną ilość dziel teologicznych z księgozbioru Piotra z Poznania w Alwerni, dla potrzeb studium. Uzyskal zapewne na to zgodę żyjącego jeszcze wówczas Piotra. Studium krakowskie otrzymalo wtedy dzielo Fabera "Dysputy teologiczne o predestynacji”, "Komentarze do trzeciej ksiegi Sentencji Jana Dunsa Scota", w opracowaniu Piotra Tartaretusa 44 , "Dysputy teologiczne” Teodora Smisinga ${ }^{45}$ oraz "Sumę teologii spekulatywnej i moralnej" z "Komentarzem do Sentencji Scota” w opracowaniu Franciszka de Pitigianis" ${ }^{46}$, a także dziela: Hugona Cavellusa "Kwestie Scota"47 i Jana Rady "Kontrowersje"48. To ostatnie otrzymal do użytku wlasnego Leonard Starczewski.

Noty dedykacyjne umieścili na podręcznikach teologii ofiarowanych studium krakowskiemu, prowincjałowie Jacek Stradomski i Franciszek Dzielowski. Aleksy Piotrkowczyk przekazał bibliotece książki o treści prawnej i kaznodziejskiej, a prowincjal Antoni Stefanowicz dwa świeżo wydane dziela teologiczne i jeden zbiór kazań ${ }^{49}$. Stefan Lędzki wspomógl księgozbiór prze-

$\$ 2$ E. Rodericus, Qunestiones regulntes et canonicue. T. 1. An 1616. - Na k. tyt. nota wlasn. z nazwiskiem Campy i przeznaczeniem książki do klasztoru Żlóbek w Kr. (KBPBK).

43 Joannes de Bassolis, Open... in 4. Libris Sententinmm" Parisis (brw) /ante 1500/ (KBPBK).

4 P. Tartaretus, Lucidissinn comnentnin size (ut tocant) Repertoria in 3. Librum Sententinnm J. Dums Soti. Ve 1607. - Na k. tyt. nota prowen. K. Strzaly z 1654 r. (KBPBK).

45 T. Smising, Disputationes theologicne. T. 1. De Deo uno. An 1626. - Na k. tyt. in verso nota K. Strzaly przeznaczająca dzielo do biblioteki konwentu krakowskiego na Stradomiu (KBPBK).

46 Franciscus de Pitigianis, Summ theologine speculatizue et moralis. Ve 1613. - Nota wlasn. lektora filozofii konwentu stradomskiego, Ludwika Bieżanowskiego - na k. tyt. Na k. tyt. verso, wicariusz provincji malopol. - lit., K. Strzala przeznacza książkę dla biblioteki konwentu krakowskiego bern. (KBPBK).

17 H. Cavellus, Jonnnis Scoti qunestiones super libros Aristotelis. Ly 1625 . - Na k. tyt. informacja u prŁynaieżności ksiaż̉i do prywatnego uzytiku Stanisiawa janeckiego; na k. tyt. v. K.Strzata aplikuje dzielo do księgozbioru konwentu krak. (KBPBK).

48 J. Rada, Controversine super 3. Sententianim librum. R /brw ok. 1614/. - Nota na k. tyt.: "Leonardi Starczewski usus proprius"; na k. przedtyt. informacja, iż dzielo nabyto w Poznaniu za 3 floreny z jalmużny Zofii z Opalenicy Leszczyńskiej; na k. tyt. v. K. Strzala przeznacza książkę w 1654 r. do bibl. konwentu na Stradomiu (KBPBK).

49 Byly to dziela: C. Brancasio, De Angelis. Na 1646 - Nota z nazwiskiem A. Stefanowicza z r. 1662; tenże, De Deo trino et uno. Na 1640 (Nota jak wyżej); E. Naxera, Prediche per ln domeniche del 'Avoento. Ve 1658. - Nota z nazwiskiem Stefanowicza (KBPBK). 
kazując dzielo teologiczne zakupione w Rzymie do prywatnego użytku tamtejszego studenta, Jacka Wegrzynowicza, który je przeznaczył po powrocie z Rzymu do klasztoru radomskiego. Tenże prowincjal przypisał "Dysputy" Fabera i antwerpskic wydanie „Komentarzy ... do sentencji Scota” autorstwa Piotra z Poznania również studium w Krakowie. Z kolei Gabriel Rottermund dwa wydania dziela Franciszka Macedo "Collationes nauki Tomasza i Scota" (1671, 1680) otrzymane od Bernardyna Zebrzydowskiego przekazal w 1686 r. do biblioteki studium krakowskiego łącznie z dzielem Brunona Hassainga pt. „Przywileje zakonne” (1671), będace wlasnościa Franciszka Dziclowskiego do jego śmierci w 1681 r. Prowincjal Ludwik Skrobkowicz „Encyklopedie moralna" Marcelina de Pisa wydaną w Paryżu w 1644 r. przekazal w 1649 r. klasztorowi na "Żłóbku” w Krakowie a Franciszek Zarzecki, rządzący jako prowincjal $w$ latach 1645-1647, nabyte po zmarlym zakonniku dzielo "Zwierciadlo Braci Mniejszych" (1509) oraz "Komentarz do Sentencji Scota" Franciszka Velasco Castillo przeznaczył w 1645 r. dla biblioteki studium w Krakowie. Jedną tylko książkę, mianowicie „Jana Dunsa Scota kwestie na księgi Arystotelesa" w opracowaniu Hugona Cavellusa (1625) podarowal tejże bibliotece pierwszy prowincjal prowincji małopolskiej, Michal Haller w roku $1628^{50}$.

Stanislaw Bojanecki, kapelan wojskowy i teolog, cieszacy się zaufaniem króla Władysława IV, jako kustosz kustoszy prowincji ruskiej podarowal dla studium tejże prowincji dzię̧o Piotra z Poznania pt. "Komentarze do nauki Jana Dunsa Scota"51, a nastepnie w czasie bytności we Włoszech w 1633/34 z poselstwem Jerzego Ossolińskiego nabył w Wenecji dzieło Jana Zamory "O doskonalości Bogarodzicy Maryi" (1634) ${ }^{52}$ i przeznaczył je w 1637 r. dla krakowskicgo kaznodziei.

Informacje o bibliotece konwenckiej Św. Bernardyna ze Sieny, zaczerpniẹte $z$ not proweniencyjnych, wskazuja przede wszystkim na ludzi zainteresowanych nabywaniem dzieł dla księgozbioru, a także na sposoby i środki służące do ich zdobywania. Owe noty dostarczaja również pewnych wiadomości o czytelnikach, o lektorach, studentach, kaznodziejach, infirmarzach, dla których nabywane książki były po prostu warsztatem $w$ wykonywanym przez nich zawodzie czy urzędzie zakonnym.

50 Zarówno Cavellus jak i inni skotyści w XVIl w. uważali "Quaestiones do dzieł Arystotelesal" za autentyczne dzielo J. Dunsa Scota i pisali do nich swoje komentarze. Nowsze badania wykazaly jednak, że nie bylo to autentyczne dzielo tego autora. - por. W. and M. Kneale, The development of logic. Ox 1986 s. 140.

51 Petrus Posnaniensis, Commentaria in doctrinam J. Duus Scoti. Ve 1626. - Na k. tyt. (?) nota z nazwiskiem S. Bojaneckiego (KBPBK).

52 J. Zamora (Utinensis), De eminentissima Deiparae Virginis perfectione libri tres. /bmw/ 1626. - Nota S. Bojaneckiego z 1637 r. przeznaczajaca księge do celi kaznodziei stradomskiego (KBPBK). 


\section{PROWENIENCJA DZIEE \\ W BIBLIOTECE FRANCISZKANÓW-REFORMATÓW}

Biblioteka konwentu Św. Kazimierza w Krakowie, podobnie jak bernardyńska na Stradomiu była $w$ dużej mierze biblioteką studium zakonnego filozofii i teologii, a jej początki sięgaly jeszcze pierwszego klasztoru na Garbarach. Zapisywali jej swoje książki kanonicy krakowscy, zarówno katedralni jak i kolegiaccy, m.in. Krzysztof Sapalski (Sapelius)53, Jakub Górski, Stanislaw Temberski, Stanisław Ossędowski ${ }^{54}$, Stanisław Wieczorkowski ${ }^{55}$, Kazimierz Sepetowski ${ }^{56}$, Pawel Jan Wojewódzki ${ }^{57}$, Wawrzyniec Wosiński ${ }^{58}$, Bartłomiej Tumliński ${ }^{59}$ i Franciszek Józef Przewoski ${ }^{60}$. Wśród ofiarodawców znaleźli się też aptekarze krakowscy: Walenty Pfeil ${ }^{61}$ i Jerzy Pipan junior ${ }^{62}$, oraz lekarze: Stanisław Wosiński63, Walenty Fon-

53 Sapalski ofiarowal reformatom dzieło J. Lopeza, Epitome sanctorum patmin ... et Origine, Basilio, Chrisostomo, Hieronimo, Ambrosio, Augustino digesta in 4 tomos. An 1622. - Na k. przedtyt. nota Sapalskiego przekazująca dzielo krakowskim duchakom, przekreślona późniejsza ręką; nota innej ręki wyrażajaca prawa wlasnościowe konwentu krak. ref.

5t Bliższe dane o ksiażkach przekazanych przez kanoników: J. Córskiego, S. Temberskiego, S. Ossędowskiego zamieszczamy poniżej.

55 S. Wieczorkowski przekazal dzielo: Aristoteles Stagirita, Prisicorum libri VIII. T. 2 Ly $1579-$ z nota wlasn. z 1635 r. na k. tyt.

56 P. Mieszkowski (editor), Institutio peregrinationum peregrinamtibus ... Lv 1625. - Nota wlas. $z$ nazwiskiem K. Sepetowskiego na $k$. tyt. $z$ data 1635 oraz nota innej ręki: "Ex testamento legatus Conventui ad S. Casimirum Cracoviae. A. 1643" (BKRK 1. 626).

57 A. Paciuchellius, Tractatus de patientia ... Mn 1677. - Nota prowen. z nazwiskiem P.J. Wojewódzkjego (zm. 1693); inne dzielo: „Plutarchi ... qune extant omnin ... latinn interpretatione H. Cruserii et G. Xylandrii ... F 1620. - Nota na k. tyt.: „Ex catahalogo Stanislai Laurentii Wosiński, ex testamento Rev. Pauli Wojewódzki" (BKRK, sygnatury: 1.187 i 0.148 ).

58 Nota z nazwiskiem S.W. Wosińskiego znajdowala się na ksiaźce z defektem $k$. tyt. IClasses Belgicae] autorstwa zapewne J. Orbers'a i Heinricha von Hasten (podpisanych pod dedykacja) [Lei 1612]. - Nota wlasn.: „Stanislaus Wosiniski Crac/oviensis/ ph/ilosophiae/ bacc/alaureus/" (BKRK O.161).

59 Podarowal reformatom dzielo Kartezjusza "Specimina philosophine" Am 1644. - Nota whasn. na k. tyt. (BKRK M. 243).

60 Commentarii Collegii Coinbricensis S.J.: In 4. Libros Sententiartum, De coelo, meteorologici et Partu materizlin Aristotelis. Kö 1603. - Nota wlasn. F.J. Przewoskiego na k. tyt. (BKRK M.191).

61 J. Pasiecznik, Kościót i klnsztor reformatów w Krakowie. Kr. 1978 s. 158. - Poza jedyna wzmianka Pasiecznika o Pfeilu jako ofiarodawcy nie udalo się odszukać noty własnościowej lub z jego nazwiskiem.

62 Aptekarz i rajca krakowski Jerzy Pipan (zm. 1648) legowal ksiegozbiór swojemu synowi Jerzemu również aptekarzowi i rajcy (zm. 1693), a ten $w$ drugiej polowie XVII $w$. ofiarowal reformatom dzieło hiszpańskiego jezuity Benedykta Pereriusa (Perejry) "De communtibus omntium rerum naturalium principiis et affectionibus libri $X V^{\prime \prime}$ (R 1576). - Por. J. Bieniarzówna, Pipan Jerzy, w: PSB, t. 26. s. 525, 526. Ponadto noty prowen. na k. tyt. (BKRK).

63 Etykn Nikomachejskn (De moribus ad Nicomachum). Ve 1558 - Nota wlasn. z nazwiskiem S. Wosińskiego znajduje się na k.tyt. Ponadto Wosiński podarowal opracowanie medyczne Andrzeja 
tanus $^{64}$ i Marcin Leszczynowicz ${ }^{65}$, jak również rajca $z$ Kazimierza pod Krakowem, Maciej Kazimierz Treter ${ }^{66}$. Wśród trzydziestu innych nazwisk zamieszczonych w notach wlasnościowych, jako ofiarodawcy jednej lub dwu książek występują: wenecjanin Hieronim Mazza ${ }^{67}$ (1570), na dziele włączonym do księgozbioru w 1648 r., następnie Jan Ungler (pocz. XVII w. $)^{68}$, Iwowianin Aureliusz Alembek ${ }^{69}$, profesor Akademii Zamojskiej Wojciech Gryglicki ${ }^{70}$, nieznany $z$ imienia dworzanin radziwillowski Tetrażycki ${ }^{71}$ (po 1598).

Ciekawa zapiska proweniencyjna znalazła się na podręczniku działań artyleryjskich pt. "Peribologia oder Bericht”, wydanym we Frankfurcie nad Menem w 1640 r.72. Pierwotnym wlaścicielem dziela byl znany z "Trylogii" Sienkiewicza general artylerii koronnej Krzysztof Grodzicki. Czyżby on sam wkleił na początku narysowany ręcznie plan Zamościa z XVII w.? Egzemplarz

Argoli: De dielus criticis et aegrorun decubitu ... I'd 1652. - Nota wlasn. S. Wosińskiego na k.tyt. (BKRK $\mathrm{J} .200$ ).

64 $\mathrm{Z}$ jego ksiegozbioru pochodzila wykladnia snów: Artemidorus Daldianus: De somnionum interpretatione libri $V$. Ly 1546 . Był to zapewne dar Wojciecha Strażyca z 1644 r. a jego wlaścicielem iv wieku XVI byl Fontanus, matematyk, lekarz, rektor Akademii Krakowskiej. Z poczatkiem XVIII w. ksiażka ta byla wlasnościa Stanistawa Slowakowicza. - Por. A. Birkenmajer, Fontanıı IValentu. W: PSB. t. 7 s. 62 oraz noty wlasn. wszystkich wymienionych wlaścicieli sennika, na karcie tytulowej (BKRK).

65 Whàsnością Leszczynowicza bylo dzielo astronomiczne W. Eichstadiusa pt. „Epemeritum (sic) noinrum et motutum coelestium ab 1651 ad 1665 descriptio" (Gd 1644). - Noty prowen. na k. tyt. (BKRK M.97).

66 Maciej Kazimierz Treter (zm. 1692) rajca kazimierski i doktor prawa ofiarowal reformatom w 1657 r. traktat astronomiczny autorstwa J. Garcacusa pt. "Tractatus brezis et utilis de erigendis figuris coeli ..." (Wittembergae 1556) oraz klocek zawierajacy m.in. noty dyplomatyczne cesarza Leopolda i króla szwedzkiego Karola Gustawa (ok. 1658). - Na k. tyt. ekslibris Tretera. (BKRK sygn. M.79 i B.152). - H. Eug. Wyczawski, Treter M.K. W: SPTK, t. 4. W. 1983 s. 344.

$67 \mathrm{H}$. Mazza w 1570 r. byl w posiadaniu ksiażki „Epitone catenae aulrene D. Thomae in 4. Evangelin" (An 1625). - Nota whasn. na k. tyt. (BKRK).

${ }_{68}$ J. Bagnacaballensis (Montanari), Exercitin spiritualia /bmrw/ (Kr. 1622?). - Nota na k.tyt.:,Ex libris Joannis Ungier".

69 Dzielo ofiarowane przez A. Bryknera (,J. Duns Scotus, Commentarin in XII libros Metaphisicae Aristotelis". (/bmw/ 1501) posiadalo na k. Al notę 2 nazwiskiem wcześniejszego wlaściciela Aureliusza Alembeka (BKRK M.177).

${ }^{70}$ Książkę należaca do Wojciecha Greglickiego pt. "De generatione et comuptione” autorstwa P. Aresiusa (Me 1617), po śmierci whaściciela przejal doktor filozofii i senior Bursy Prawników Baltazar Tumliński, a następnie ofiarowal ja reformatom krakowskim (ok. 1680). /Estr.: Bibliogr. t. 31 s. $387 / .-$ O. Greglickim por. J. Reychman, Greglicius Wojciech (zm. 1670). W: PSB. t. 9. s. 76.

71 J. Lipsius, De militia Romana libri V. Commentarius at Polybitum. An 1598. - Nota wlasn. na k. tyt.: „Ex libris Tetrazycki de Tetrazyi (sic) Radivilianus aulicus” (BKRK) O.53).

72 Jest to zbiór planów strategicznych artylerii. Na k. tyt. znajduje się nota proweniencyjna w j. polskim: „Księga po slaivnej pamięci Jaśnie Wielmożnym Panu Krzysztofie Grodzickim kasztelanie kamienieckim, staroście drohobyckim, generale artylerii koronnej, pułkowniku JKM pozostala". Następnie zapis innej ręki: „General Boguslaw Fredro castel/lanus/ lwowski”. (BKRK $0.244)$ 
przeszedł później w ręce kasztelana lwowskiego, Jerzego Bogusława Fredry, który ofiarowal go reformatom.

Wśród wymienionych ofiarodawców książek oraz wcześniejszych właścicieli dziel, które następnie znalazly się w bibliotece reformatów w Krakowie wysunęly się na czolo pod względem ilości przekazanych pozycji, następujące osoby: jako pierwszy, profesor szkól Nowodworskich, Adam Brykner (34) ${ }^{33}$, profesor prawa Akademii Krakowskiej i jej rektor Jakub Górski (15), kanonik kilku kapitul katedralnych i profesor Akademii Stanislaw Temberski (13), pralat kolegiaty Wszystkich Świętych $w$ Krakowie i profesor Akademii Stanisław Ossędowski (6), doktor filozofii i medycyny oraz rajca Stanisław Wosiński (5), bakałarz Walerian Królik (5), mieszczka Agnieszka Wolska (5) pochodząca z kręgów bliżej związanych z kościolem Św. Kazimierza oraz kanonik kolegiaty Wszystkich Świętych i senior Bursy Prawników, Baltazar Tumliński (3).

Najliczniejszą grupę książek, opatrzoną 34 wpisami wlasnościowymi, stanowily dary wniesione do klasztoru w 1667 r. przez krakowianina, Adama Bryknera, który wstapił do reformatów jako kaplan, notariusz apostolski, doktor obojga praw, a następnie profesor Akademii Krakowskiej. Pierwszym miejscem jego działalności $w$ zakonie byl dom nowicjatu $w$ Wieliczce. Byl też kilka razy gwardianem klasztorów, m.in. w Krakowie, a w latach 1689-1692 zastępca prowincjala. Ksiażki ofiarowane przez Bryknera zostaly przeznaczone dla studium zakonnego krakowskiego konwentu. Wśród tych dziel przeważały pozycje filozoficzne, prawne $i$ historyczne. Znalazły się $w$ tej grupie dwa najstarsze u reformatów wydania komentarzy do "Metafizyki" Arystotelesa opracowane przez Antoniego Trombette (1492) i "Komentarz" do tegoż, J.D. Scota (1501). Pierwsze z nich bylo w XVI w. wlasnością kaznodziei Andrzeja Lwowczyka (nota z 1538), następnie bakalarza sztuk wyzwolonych, Stanislawa Lwowczyka (nota $z$ 1544), a w latach dwudziestych XVII w. należalo do księgozbioru Stanisława Werlońskiego, od którego nabyl je ofiarodawca. Z kolei "Komentarz" Scota nabyl Brykner od studenta krakowskiego Aureliusza Alembeka, który wcześniej kupił to dzieło na krakowskiej tandecie. Do filozoficznych książek darowanych reformatom przez Bryknera należał też podręcznik metafizyki Klemensa Timplera (1616) oraz komentarz Giphaniusa do "Polityków" Arystotelesa (wyd. 1608). Z zakresu prawa znalazly się tylko dwie pozycje, Emanuela Rodericusa "Nowy zbiór przywilejów mendykanckich" (wyd. 1613), którego nabycie świadczy o wcześniejszych już zainteresowaniach Bryknera zakonnym życiem - oraz dzieło Piotra Męczennika Urceanusa: „Summariusz konstytucji, deklaracji i statutów" (wyd. 1620). Największą grupe wśród tych darów stanowily opracowania historyczne i polityczno-geograficzne, którymi Brykner interesował się od czasu swoich studiów uniwersytec-

73 G.A. Wiśniowski, Brykner Adnm. W: SPTK, t. 1 s. 233. 
kich. Znalazly się tu takie opracowania, jak "Dzielo o Flandrii" Jakuba Marchantiusa (wyd. 1596), „Dzieje Persów” Piotra Bizarusa (wyd. 1601), „Cnota rzymska" Mikolaja Reusnera (wyd. 1604), dzieło encyklopedyczne Jana Henryka Alsteda pt. "Skarbiec Chronologiczny" (wyd. 1650) i kilka innych. Zbiór darowany przez Bryknera zamykaja dwa opracowania hagiograficzne: Broverusa "Firmament wybitnych i świętych mężów" (1616) oraz dzieło norbertanina, Marcina Merza pt. "Norbert tryumfujacy" (1628) a także jedyny podręcznik matematyki Kaspra Ensela "Thamaturgus mathematicus" (1651). Przekazane przez Adama Bryknera książki stanowily fragment typowego księgozbioru profesora Szkół Nowodworskich w wieku XVII, o specjalizacji filozoficzno-prawnej z dodatkowymi pozycjami świadczacymi o prywatnych zainteresowaniach historycznych ofiarodawcy ${ }^{74}$.

Na drugim miejscu wśród dobrodziejów biblioteki studium reformackiego w Krakowie znalazł się Jakub Górski, wieloletni profesor prawa w Akademii Krakowskiej oraz jej rektor w latach 1651-1652. Obok działalności uniwersyteckiej Jakub Górski pracowal także w kurii diecezjalnej krakowskiej u boku biskupa Piotra Gembickiego, przez którego zostal wyróżniony notariatem apostolskim $i$ powolany na osobistego doradce ordynariusza ${ }^{75}$. Przekazane przez Górskiego dla konwentu reformatów krakowskich książki to przeważnie komentarze ksiąg biblijnych, a wśród nich "Komentarze na listy kanoniczne” (wyd. 1530) i na "Psalmy" (1539), kartuza Dionizego Rickela oraz "Dzieła" Hieronima w opracowaniu Marcina Victoriusa (wyd. 1579). Na uwage zasługuja też ofiarowane przez Górskiego pozycje ascetyczne, m.in. franciszkanina Salutiusa "Światło duszy na drodze doskonalości" (1613) oraz wspóloprawne pozycje wydane wcześniej: Bonawentury "Zwierciadło Bożej milości", nieznanego autora "O sztuce życia i umierania" (1510) i Korneliusza Musiusa "Zwierciadło czyli wzór prawdziwego mnicha". To ostatnie w wydaniu krakowskim z $1617 \mathrm{r}^{76}, \mathrm{z}$ nieznanej bliżej drukarni. Do tej samej grupy ascetyków, ale w osobnym woluminie, należal "Heraklit chrześcijański" Piotra Besseusa $w$ wydaniu kolońskim z $1614 \mathrm{r} \cdot{ }^{77}$.

Do ciekawszych nabytków $w$ bibliotece reformatów $w$ Krakowie pochodzących z daru Jakuba Górskiego należal także inny klocek ${ }^{78}$, złożony z "Dziel" Augustyna Dathusa wydanych w Wenecji, w 1516 r. oraz

74 Noty wlasnościowe i proweniencyjne z nazwiskiem Adama Bryknera znajdują się w dzielach BKRK z nastẹpującymi sygnaturami: B.26, H.29 (B.106), J.246, L.149, I.104, M.7, M.23, M.64, M.175, M.19(?), M.220, M.223, 0.20, O.22, 0.29(?), O.7, 0.10, O.13, 0.48, 0.55, 0.56, 0.59, 0.63, 0.64, $0.70,0.151,0.152,0.158,0.183,0.165,0.169$.

75 H. Eug. Wyczawski, Biskup Piotr Gembicki, 1585-1657. Kr. 1957 s. 176, 177; L. Hajdukiewicz, Gembicki Piotr. W: I'SB, t. 8 s. $440,441$.

76 Jest to klocek $z$ pięcioma pozycjami z ascetyki, wydanymi w XVI i XVII w. (BKRK L.239).

77 Noty proweniencyjne $\mathrm{z}$ nazwiskiem J. Górskiego znajduja się m.in. $w$ dzielach o nastepujacych sygnaturach: B.256, B.266, B.270, B.278, B.200, 1.290 .

78 Pozycja ta występuje w BKRK pod sygn. W.4. 
rękopiśmiennych oracji i pism różnych autorów. W tym rẹkopisie wlączonym do klocka znajduja się m.in. "Oracja” Joachima de Wad (Vadianusa) profesora Uniwersytetu wiedeńskiego, wygloszona w imieniu Akademii Krakowskiej podczas spotkania cesarza i trzech królów w Wiedniu w 1515 r., w tym także Zygmunta I Starego oraz "Pieśn”" (Carmen) tegoż Joachima Vadianusa na cześć tego polskiego monarchy. Byla tam również "Pieśn" (Carmen) Andrzeja Krzyckiego na zaślubiny Zygmunta Augusta z Barbara Radziwiłlówną i tegoż "Oracja” na ingres biskupa krakowskiego Piotra Tomickiego.

Kolejny co do wielkości byi zapisany reformatom księgozbiór kanonika kilku kapituł i profesora prawa Akademii Krakowskiej, Stanislawa Temberskiego, znanego z opozycji przeciw biskupowi krakowskiemu Piotrowi Gembickiemu ${ }^{79}$. Zapisal on reformatom kilka komentarzy biblijnych oraz kilka prac z zakresu logiki i filozofii teoretycznej, w tym "Dzieła wszystkie" Arystotelesa w wydaniu bazylejskim z 1548 r., które wcześniej byly wlasnościa kanonika kapituły kolegiackiej Św. Krzyża w Krakowie, Mikolaja Bodzencina (sic). Ponadto darem Temberskiego dla konwentu Św. Kazimicrza było zbiorowe wydanic komentarzy autorów jezuickich z Koimbry ${ }^{80}$ oraz "Dziela logiczne" Jakuba Zabarelli (wyd. 1597). Z komentarzy biblijnych Temberski podarowal reformatom objaśnienia do wszystkich listów św. Pawła autorstwa Dionizego Rijckela, kartuza oraz „Komentarze” do Lamentacji Jeremiasza, karmelity bosego Jana od Jezusa Maryi (wyd. 1611) ${ }^{81}$. Niektóre książki zapisane reformatom otrzymal Temberski od swojego wuja, kanonika z Ostrawy, Stanisława Wojciechowskiego. Wśród nich znalazly się: "Raj duszy" Alberta Wielkiego (1578) i Roberta Bellarmina "O sztuce dobrego umierania" (1620).

Wśród innych pomniejszych ofiarodawców należy wymienić kanonika kolegiaty W.W. Świętych $w$ Krakowie i profesora prawa $w$ Akademii Krakowskiej Stanisława Ossędowskiego (zm. 1669) ${ }^{82}$ i jego ucznia bakałarza Waleriana Królika. Pierwszy $\mathrm{z}$ nich $\mathrm{w}$ latach 40-tych XVII w. i $w$ roku 1661 ofiarowal bibliotece studium reformatów w Krakowie kilka pozycji wydanych $w$ drugiej polowie XVI w. i $w$ wieku XVII, m.in. św. Augustyna "Wyznań ksiagg 13" (wyd. 1581), Dionizego Rijckela "O doskonałej wzgardzie świata" (wyd. 1600), Antoniego Guevary tłumaczenie z hiszpańskiego na język laciński pt. „Oratorium zakonne” (wyd. 1614), jak również komentarz

\footnotetext{
79 H. Eug. Wyczawski, Biskup Piotr Gembicki, s. 284, 285.

80 Byly to komentarze do dziel Arystotelesa pt. "De generatione et corruptione" wydane w Koimbrze w 1601 r.

81 Książki z księgozbioru Temberskiego wystẹpuja w BKRK pod następującymi sygnaturami: B.201, B.273, 1.257, I.249, M.169, M.184, M.189, M.192.

82 W. Baczkowska, Ossędouski Stanistaiv. W: PSB, t. 24, s. 386.
} 
Piotra Victoriusa do pierwszej księgi Arystotelesa „O sztuce poetyckicj” (wyd. $1560)^{83}$.

Po śmierci Waleriana Królika (zm. 1661), ucznia Ossędowskiego, napłynęły do biblioteki Św. Kazimierz niektóre książki, a wśród nich dzieło Andrzeja Eborensis "Sentencje tak pogańskich jak i chrześcijańskich autorów" (wyd. 1593), Piotra Legeneriusza „Zbiór znaczniejszych sentencji, porviedzeń... z dzieł Cycerona, Domostenesa i innych wybitnych autorów" (wyd 1615). Poza tym od tegoż dobrodzieja pochodziło dzieło Ksenofonta „O wyprawie Cyrusa Mlodszego" (wyd. w XVI w.) ofiarowane reformatom zaraz po śmierci Królika (zm. 1661), oraz kilka ascetyków wydanych ok. 1510 r. i wspóloprawnych, m.in. autorstwa Jana Chrzciciela Mantuanusa "O cierpliwości" i Augustyna Dathusa "O życiu blogosławionym". Kilka innych ascetyków w języku polskim, wydanych w Krakowie, Lwowie i Wilnie w pierwszej polowie XVII w. ofiarowała pobożna mieszczka, Agnieszka Wolska.

Kilkanaście dziel, przeważnie ascetycznych, należących do bibliotek różnych klasztorów reformackich znalazlo sie w konwencie Sw. Kazimierza w Krakowie ze względu na potrzeby tamtejszemu studium teologii. Najwięcej, bo osiem pozycji przewieziono z klasztoru na Górze Św. Anny na Ślasku. Wśród nich znalazły się „Konstytucje generalne Familii Cismontańskiej”, uchwalone na kapitule generalnej w Valladolid w Hiszpanii w 1593 r. w wydaniu weneckim z 1598 r., ponadto kilka dzieł ascetycznych: Hadriana Lyraeusa, Drekseliusa, Alfonsa Rodericiusa, Piotra z Alkantary i Kaspra Druźbickiego. Nota proweniencyjna zamieszczona $w$ tym ostatnim wskazuje na przeniesienie dziela do konwentu krakowskiego, którego dokonano z polecenia prowincjała w 1698 r.

Z macierzystego klasztoru w Gliwicach dostarczono dla biblioteki studium w Krakowie "Dziela logiczne" Jakuba Zabarelli (wyd. 1597), karmelity bosego Jana od Jezusa Maryi opracowanie pt. „Dyscyplina klasztorna” (1616), oraz Stefana Brulefera "Komentarz do 4. ksiag Sentencji wedlug Bonawentury" (Bazylea 1551) które na przełomie XVI i XVIl w. było w posiadaniu socjusza Gabriela z Gródka, Adama Pogroszewskiego. Z klasztoru w Wieliczce przekazano do Krakowa tom pierwszy "Dzieł wszystkich" cenionego wówczas pisarza ascetycznego, reformatora benedyktynów we Francji, Ludwika de Blois (zm. 1566), a ze Stopnicy przewieziono w 1700 r. trzecią ksiegę "Pymandra", dzieło filozoficzno-teologiczne pisarza bernardyńskiego Hannibala Rossellego (wyd. 1586), a po roku 1707 "Soliloquia christiana" jezuity Wojciecha Tylkowskiego (wyd. 1707).

83 Dzielo A. Guevary (,Oratorium religiosorum ... Kö 1614) zostało przez Ossędowskiego przeznaczone dla reformatów w Pińczowie po 1640 r. - Por. notę prowen. na k. tyt.: „Ex libris Danielis Kukliński ... magister nobilis Stanislaus Ossędowski patribus reformatis bernardinis (sic) offert 164t? Pinczoviae". - Inne pozycje pochodzace $z$ daru Ossędowskiego występują w BKRK pod sygnaturami: 1.330, 1.573, I.15(?), M.355. 
Zdarzało się niekiedy, iż sami autorzy przekazywali swoje książki do biblioteki studium przy konwencie Sw. Kazimierza, albo też poszczególni zakonnicy zwracali dziela darowane im do prywatnego użytku, względnie wcielano je do biblioteki po śmierci zakonnego czytelnika. Jezuita Stanislaw Gloskowski podarował reformatom swoje dzieło pt. „Fragmenty filozofii powszechnej" wydane w Kaliszu w 1694 r., a gwardian reformackiego klasztoru w Bieczu, Franciszek Marcinkowski przekazal wspóloprawne dziela z XVI w. mianowicie podręcznik filozofii Hieronima Wildenberga, Alberta Wielkiego „Komentarze do Arystotelesa" i druga księge dzieła Cycerona "O naturze bogów". Drugi tom "Dziel" Seneki, wydany w 1593 r., otrzymala biblioteka studium po śmierci nieznanego z nazwiska reformaty Romana, a w $1590 \mathrm{r}$. zakupione w Krakowie dzielo Franciszka Costerusa "O życiu i chwale NMP” (1587) przez nieznanego z nazwiska brata Macieja z nieokreślonego bliżej konwentu krakowskiego zostało przekazane bibliotece klasztornej, zapewne po jego przejściu do reformatów na początku XVII w. Z kolei „Kwestie na osiem ksiag Fizyków Arystotelesa" autorstwa Jana z Jandun (wyd. 1596) nabyl lektor filozofii Antoni z Leżajska, dzięki pomocy finansowej dobrodzieja Macieja Przybyło, zaznaczając, że ma ono służyć dla studium, a nie dla konwentu. Natomiast „Hieroglifica czyli o świętościach egipskich” Jana Waleriana Pieriusa (b.r.w.) byly własnościa zakomnika Stanislawa Juthowida (?) zanim weszly w skład księgozbioru klasztornego. Podobnie „Kompendium spraw zakonnych” Emanuela Rodericusa (wyd. 1622) mial w swoim zbiorze brat Marcin Ślepowroński, a "Przywileje zakonów mendykanckich i niemendykanckich według reformy Soboru Trydenckiego" wydane w Wenecji w 1610 r. stanowily wlasność nieznanego z nazwiska brata Jana. Nie wiadomo wszakże czy wymienieni posiadacze książek byli reformatami, oprócz nieznanego z nazwiska Romana, po śmicrci którego włączono książkę do biblioteki.

Nie można wykluczyć ewentualności, iż wspomniani wyżej zakonnicy byli księżmi z innych zakonów, m.in. bernardynów lub franciszkanów konwentualnych, którzy przeszli do reformatów zabierając swoje książki, względnie byli ich ofiarodawcami. Ta ostatnia ewentualność wydaje się jednak najmniej prawdopodobna, zważywszy, iż zakonnicy z obcych klasztorów tylko wyjatkowo bywali dobrodziejami bibliotek innych zakonów (np. w dowód przyjaźni). Tak było chyba tylko $\mathrm{z}$ darem reformaty Bonawentury Koralkiewicza, wikarinsza klasztoru w Brześcin, który w dowód przyjaźni ofiarowa! Dominikowi Jaworskiemu dominikaninowi, kaznodziei w Dereczynie i kapelanowi choragwi JKM - książkę Ambrożego Morlianusa "Teatr polityczny", wydaną w Gdańsku w 1645 r. Dedykacja rękopiśmienna na karcie tytułowej pochodzi z r. 1650 lub 1657 r. Z kolei "Żywot św. Dominika" Mikolaja Janseniusa OP, przełożonego na język polski przez Fabiana Birkowskiego (wyd. 1626) przed wlączeniem do biblioteki reformatów był wlasnością warszawskiego dominikanina, Wojciecha Michalowskiego. Dlugie śledzenie zapi- 
sów proweniencyjnych ujawnito tylko dwa takie przyklady $w$ całym księgozbiorze, o ile ten drugi przyklad istotnie dotyczyl daru będącego wyrazem przyjaźni.

Należy zatem przyjąć, że wymienieni właściciele, względnie użytkownicy książek, które w końcu trafiły do biblioteki konwenckiej Sw. Kazimierza byli przeważnie reformatami, a tylko niektórzy z nich zakonnikami z innych klasztorów, którzy z czasem przeszli do reformatów. W każdym razie informacje, jakie czerpiemy z zapisów proweniencyjnych nie dostarczaja wielu dowodów na to iż nabywanie ksiązek przez poszczególnych zakonników stanowiło liczące się źródlo powiększania zasobów bibliotecznych.

Zawartość krakowskich bibliotek braci mniejszych (bernardynów i reformatów) przedstawiona $w$ tym artykule stanowi odbicie zainteresowań intelektualnych ich właścicieli. Reasumując, należy wskazać na zasadnicze proporcje uwidocznione w zasobach poszczególnych działów a co za tym idzie, ustalić kolejność dziedzin wiedzy wedlug ich znaczenia $w$ życiu klasztorów i w wewnętrznym nauczaniu.

Szkoła humanistyczna, do jakiej zaliczalo się studium zakonne rozpoczynała od gramatyki języka lacińskiego, retoryki i dialektyki stanowiacych przygotowanie i swego rodzaju pomost do nauczania filozofii. Z kolei dyscypliny filozoficzne przygotowywały do głównego celu, jakim było studiowanie teologii czyli nauki o Bogu. Tym trzem etapom szkoly zakonnej odpowiadała w zasadzie zawartość bibliotek oraz kierunki ich rozwoju. Wszakże obok tradycyjnej struktury szkolnej i jej zaplecza $w$ postaci takich a nie innych książek dochodzilo zapotrzebowanie na dziela związane z charakterem działalności i życia franciszkańskiego zakonu. Regula św. Franciszka z Asyżu wytyczała braciom mniejszym kierunek kontemplacyjno-apostolski. W związku z tym wśród dyscyplin teologicznych największą grupe stanowily w bibliotekach te wszystkie publikacje i rękopisy biblioteczne, które można ogólnie nazwać jako popularyzacja doktryny, a więc kaznodziejstwo i wszelkiego rodzaju interpretacje Biblii. Równorzędne miejsce zajmowala literatura ascetyczno-mistyczna, aczkolwiek pod względem ilości pozycji w księgozbiorach ustepowała kaznodziejstwu i biblistyce. Teologia dogmatyczna nazywana spekultatywną, uważana w nauczaniu za królowę wszystkich nauk, ze względu na charakter niejako elitarny, pod względem zasobów w księgozbiorach zajmowała miejsce po ascetyce i mistyce. Dyscypliny nazywane w średniowieczu ,ancillae theologiae", w czasach nowożytnych konkurowaly skutecznie w bibliotekach zakonnych $\mathrm{z}$ teologią ścisła. Pewna nowość stanowiła literatura $\mathrm{z}$ zakresu nauk ścisłych i przyrodniczych, lekceważona i pomijana w średniowieczu zyskała na znaczeniu dopiero $w$ dobie odkryć naukowych, w wieku XVII i XVIII. Jej niewielki zasób w bibliotekach franciszkańskich $w$ Krakowie świadczył jednak o poszerzonych zainteresowaniach nowożytnego studium zakonnego. 